NBER WORKING PAPER SERIES

\title{
THE COST OF BEING TOO PATIENT
}

\author{
Paola Giuliano \\ Paola Sapienza \\ Working Paper 26677 \\ http://www.nber.org/papers/w26677
}

\author{
NATIONAL BUREAU OF ECONOMIC RESEARCH \\ 1050 Massachusetts Avenue \\ Cambridge, MA 02138 \\ January 2020
}

The views expressed herein are those of the authors and do not necessarily reflect the views of the National Bureau of Economic Research.

NBER working papers are circulated for discussion and comment purposes. They have not been peer-reviewed or been subject to the review by the NBER Board of Directors that accompanies official NBER publications.

(C) 2020 by Paola Giuliano and Paola Sapienza. All rights reserved. Short sections of text, not to exceed two paragraphs, may be quoted without explicit permission provided that full credit, including $(\mathrm{C}$ notice, is given to the source. 
The cost of being too patient

Paola Giuliano and Paola Sapienza

NBER Working Paper No. 26677

January 2020

JEL No. A0,D01,D9,Z1

\title{
ABSTRACT
}

We study the cost of being too patient on happiness. We find that the relationship between patience and various measures of subjective well-being is hump-shaped: it exists an optimal amount of patience that maximizes happiness. Beyond this optimal level, higher levels of patience have a negative impact on well-being.

\author{
Paola Giuliano \\ Anderson School of Management \\ UCLA \\ 110 Westwood Plaza \\ C517 Entrepreneurs Hall \\ Los Angeles, CA 90095-1481 \\ and IZA \\ and also NBER \\ paola.giuliano@anderson.ucla.edu \\ Paola Sapienza \\ Kellogg School of Management \\ Northwestern University \\ 2221 Campus Drive \\ Evanston, IL 60208 \\ and CEPR \\ and also NBER \\ paola-sapienza@northwestern.edu
}




\title{
The Cost of Being too Patient
}

\author{
By PaOla GiUliano AND PaOla SAPIENZA*
}

\footnotetext{
* Giuliano: UCLA Anderson School of Management, 110 Westwood Plaza, Los Angeles, CA, 90405 (e-mail: paola.giuliano@anderson.ucla.edu). Sapienza: Kellogg School of Management, Northwestern University, 2001 Sheridan Road, Evanston, IL $60208 \quad$ (e-mail: PaolaSapienza@kellogg.northwestern.edu). We thank participants at the AEA Meetings for comments that substantially improved the paper. We also thank Zachary Sauers for excellent research assistance.
}

Theoretical and empirical evidence show that patience, the ability to sacrifice the present for future rewards, helps explain economic decisions such as savings, investment in human capital, and even the wealth of nation (Chen, 2013 ; Falk et al., 2018; Figlio et al., 2019; Galor et al., 2016).

However, an excessive tendency to delay gratification can have psychological costs, as measured by many indicators of subjective well-being. Recent evidence shows that AsianAmerican students, a group scoring high in the level of patience, suffer psychological and social costs despite their strong academic success. One possible interpretation advanced in the literature is that they may suffer immediate psychological costs as a result of sacrificing the present for the future (Hsin and Xie, 2014).

In this paper, we test systematically the potential cost of being too patient by using the
Global Preference Survey (GPS) developed by Falk et al. (2018) within the framework of the 2012 Gallup World Poll data.

We focus on life satisfaction, the variable most commonly used in the existing happiness literature (Di Tella et al, 2003; Layard, 2011; Stevenson and Wolfers, 2008) and also use a variety of alternative measures of subjective well-being.

We find that excessive patience is costly for individual well-being. This result is consistent across nine different measures of subjective well-being. Our measure of patience varies from a minimum of -1.31 to a maximum of 2.76 (this measure has standardized mean of zero and standard deviation of 1 ). For one of the main well-being indices, the life evaluation index, the level of patience that maximizes happiness is equal to 1.56 , a numerical value similar to the one obtained using other wellbeing indicators.

The economic magnitude of the cost of being too patient is also significant. Moving from the highest level of life satisfaction (reached at a level of patience equal to 1.56) to the one associated with the $99^{\text {th }}$ percentile of patience implies a reduction in happiness of 0.025 , 
equivalent to roughly $22 \%$ of the estimated difference between having completed college (0.200) and having a high school diploma (0.086). When we use the "positive experience index," a summary measure about experienced well-being the day before the interview, the results are of similar magnitude: moving from a level of patience of 1.40 corresponding to the peak in the positive experience index to the $99^{\text {th }}$ percentile in patience reduces the positive experienced index by 1.07 , equivalent to $26 \%$ of the difference in happiness between those who completed college (7.16) and those with a high school diploma (3.12).

As robustness check, we present the results splitting the sample along many observable characteristics. The results confirm that the relationship is hump shaped within each group suggesting that our main findings are not driven by compositional effects.

Overall, our results suggest that excessively delaying present gratification for future rewards can have substantial well-being effects. A moderate amount of patience appears to be associated with a higher level of life satisfaction and emotional well-being.

\section{Data and variables of interest}

Our analysis uses data from the 2012 Gallup World Poll and the Global Preference Survey. The Gallup World Poll includes a wide range of individual-level background variables, such as socio-demographic information (age, gender and marital status), a large set of economic variables (income, educational attainment and labor market status), and various measures of well-being.

Falk et al. (2018) developed the Global Preference Survey by adding to the 2012 Gallup questionnaire a set of survey items to measure time preferences, risk preferences, and social preferences (altruism, positive/negative reciprocity, and trust) for representative population samples in 76 countries. Our measure of patience comes from the Global Preference Survey.

\section{A. Patience}

Falk et al. (2018) construct the patience measure using responses to two survey items, one with a quantitative and one with a qualitative format. The quantitative survey item consists of a series of five interdependent hypothetical binary choices between immediate and delayed financial rewards, a format commonly referred to as the "staircase" (or unfolding brackets) procedure. In each of the five questions, participants had to decide between receiving a payment today and a larger payment in 12 months: "Suppose you were given the choice between receiving a payment today or a payment in 12 months. We will now present to you five situations. The payment 
today is the same in each of these situations. The payment in 12 months is different in every situation. For each of these situations we would like to know which one you would choose. Please assume there is no inflation, i.e., future prices are the same as today's prices. Please consider the following: Would you rather receive amount $x$ today or $y$ in 12 months?" 1

The qualitative measure of patience is given by the respondents' self-assessment of their willingness to wait on an 11-point Likert scale: "We now ask for your willingness to act in a certain way. Please indicate your answer on a scale from 0 to 10 , where 0 means you are “completely unwilling to do so" and a 10 means you are "very willing to do so". How willing are you to give up something that is beneficial for you today in order to benefit more from that in the future?”

The summary measure of patience is a linear combination of the quantitative and qualitative survey items, using the weights obtained from the experimental validation procedure (see Falk et al. (2016) for details).

Figure 1 shows the distribution of patience in our sample (the variable is standardized with

\footnotetext{
${ }^{1}$ See Falk et al. (2018) for further details.

2 This measure of subjective well-being has been shown to be correlated with physical measures of well-being such as overall health, heart rate, sleep quality, sociability and propensity to laugh and smile (Diener, 1984, Kahneman and Krueger, 2006). This measure also tends to be relatively stable over time and it has a high test-retest correlation (Diner and Tov, 2007).
}

mean zero and standard deviation one). Patience is quite heterogeneous across individuals and most people appear to be impatient (the median is -0.29 , and the minimum and maximum are -1.31 and 2.76).

\section{[ Insert Figure 1 Here ]}

\section{B. Subjective well-being}

The Gallup World Poll includes a measure of subjective well-being in which respondents were shown a picture and told, "Here is a ladder representing the 'ladder of life.' Let's suppose the top of the ladder represents the best possible life for you; and the bottom, the worst possible life for you. On which step [between 0 and 10] of the ladder do you feel you personally stand at the present time?”. ${ }^{2}$ There are two versions of this question, one for life today and one for life in five years. Gallup also has a Life Evaluation Index which combines the two questions of well-being about life today and life in the future. This summary index can take values from 1 to 3 , where 1 indicates “suffering”, 2 indicates "struggling” and 3 indicates "thriving”. 3

\footnotetext{
${ }^{3}$ The index is calculated using the following procedure. Individuals who rate their current lives at 7 or higher, and their future at 8 or higher are coded as "thriving". Individuals are coded as "suffering" if they report their current and future lives as a 4 or lower. All other individuals are coded as "struggling".
} 
Gallup asks a series of more specific questions about the feelings of the person the day before the interview, which aim at capturing various aspects of emotional health and daily experience. We analyze all the questions related to happiness. More specifically, we select answers regarding enjoyment, happiness, worry, and sadness from the following question: "Did you experience the following feelings during a lot of the day yesterday?” (the available answers to this question were simply yes/no). ${ }^{4}$ We also use the following question: "Now, please think about yesterday, from the morning until the end of the day. Think about where you were, what you were doing, who you were with, and how you felt. Did you smile or laugh a lot yesterday?” (the available answers to this question were also yes/no).

As an additional proxy of happiness, we report results using the Positive Experience Index, a measure of experienced well-being on the day before the survey. The index can take values from 0 to $100 .^{5}$

\footnotetext{
4 We coded all of the answers in such a way that " 1 " corresponds to positive feelings and a " 0 " corresponds to negative feelings.

${ }^{5}$ Gallup uses the following five questions to calculate the index: i) "Did you feel well-rested yesterday?”; ii) "Were you treated with respect all day yesterday?”; iii) "Did you smile or laugh a lot yesterday?"; iv) "Did you learn or do something interesting yesterday?”; v) "Did you experience the following feelings during a lot of the day yesterday? What about enjoyment?". To calculate the index, Gallup applies the following procedure. The five items are recoded so
}

\section{Estimation results}

We study the relationship between individual well-being and patience by estimating the following model in the pooled sample of countries in Gallup Poll.

$$
\begin{gathered}
\text { (1) } \text { Happiness }_{i c}=\alpha \text { Patience }_{i c}+ \\
\text { PPatience }_{i c}^{2}+\gamma X_{i c}+\delta C+\varepsilon_{i c}
\end{gathered}
$$

where Happiness $s_{i c}$ is one of the well-being measures described above, $X_{i c}$ is a vector of characteristics that could influence individual well-being (level of education, household income, labor market and marital status of the person, in addition to a female dummy and a quadratic for age) and $C$ are country-fixed effects, to control for systematic differences in the level of average well-being across countries. Standard errors are clustered at the country level. ${ }^{6}$

Table 1 , columns 1 to 3 , shows a quadratic relationship between well-being and patience for all the measures of life satisfaction (life satisfaction today, in five years, or the life evaluation index). When patience is equal to 1.56 the life evaluation index reaches its peak, while for higher levels in patience, the life

\footnotetext{
that positive answers are scored as a " 1 " and all other answers (including don't know and refused) are scored as “ 0 ”. If a record has no answer from an item, that item is not eligible for inclusion in the calculations. An individual record has an index calculated if it has at least four out of five valid scores ( 0 or 1$)$. The record's final score is the mean of valid items multiplied by 100 .

6 Descriptive statistics are reported in Table A1 of the On-line Appendix.
} 
evaluation index decreases. Similar results are obtained by using measures of life satisfaction today and in five years.

The magnitude of the well-being cost of being too patient is also economically and statistically significant. Moving from a level of patience corresponding to the peak in the life evaluation index to the $99^{\text {th }}$ percentile in patience reduces the life evaluation index by 0.025 , equivalent to $22 \%$ of the differential effect in happiness of having a college degree (0.200) with respect to a high school diploma (0.086). ${ }^{7}$

Table 1, columns 4-9, shows the relationship between patience and a variety of alternative measures of self-reported well-being on the day before the interview, capturing various aspects of emotional health and daily experience, as well as the summary measure "positive experience index." With the exception of one variable (whether the person was worried the day before the survey), all of these additional measures confirm our main finding. When we use the "positive experience index" (column 9), the level of patience maximizing this index is 1.40. The magnitude of the effect is of the same

\footnotetext{
7 All of the controls' coefficients have signs and magnitudes consistent with the literature (Di Tella et al., 2003, Stevenson and Wolfers, 2008): income positively correlates with happiness, together with education and employment (see Table A2 of the On-line appendix). In the On-line Appendix (Table A3), we also report a specification which includes just the demographic controls (age and
}

order of Table 1: moving the level of patience from 1.40 to 2.64 ( $99^{\text {th }}$ percentile) implies a reduction in the positive experience index of 1.07 , equivalent to $26 \%$ of the difference in happiness between having a college degree (7.16) and having a high school diploma and no high school diploma (3.12).

\section{[ Insert Table 1 Here ]}

While these results are correlational, since the relationship is hump shaped, we believe it is unlikely that they are driven by standard concerns of omitted variables and reverse causality. The results also hold when we split the sample along all observable characteristics included in the regression or when we split the sample by countries with a level of patience below or above the median, ruling out that our findings are driven by compositional effects. ${ }^{8}$

The relationship between patience and wellbeing is always hump-shaped: there is a moderate amount of patience that maximizes the level of happiness.

gender), together with country fixed effects and the results are very similar.

8 In the on-line appendix (Tables A4-A5), we report the results of different splits of our sample based on age, gender, education, income, marital and labor market status, for the life evaluation and the positive experience indices. In the same Tables we also report the split by countries below or above (or equal) the level of patience in the sample. 


\section{Conclusions}

This paper explores the cost of being too patient. We establish that the relationship between patience and various measures of subjective and experienced well-being is hump-shaped: there exists an optimal amount of patience that maximizes happiness. Beyond this optimal level, higher levels of patience have a negative impact on well-being. The data suggests that only very high levels of patience are costly, therefore the societal benefits of delaying gratification on average exceeds the cost of being too patient. This result helps us reconcile our findings with the literature that emphasized the economic benefits of patience.

\section{REFERENCES}

Chen, M. Keith. 2013. "The Effect of Language on Economic Behavior: Evidence from Savings Rates, Health Behavior, and Retirement Assets”, American Economic Review, 103, 690-731.

Diener, Ed, 1984. "Subjective Well-Being”, Psychological Bulletin, 95 (3): 542-75.

Diener, Ed and William Tov, 2007. "Culture and Subjective Well-Being”. In Shinobu Kitayama and Dov Cohen, eds. Handbook of Cultural Psychology. New York: Guilford.

Di Tella, Rafael, Robert MacCulloch and Andrew Oswald, 2003. "The
Macroeconomics of Happiness", Review of

Economics and Statistics, 85 (4), 809-827.

Falk, Armin, Benke Anke, Dohmen Thomas and Benjamin Enke. 2018. "Global Evidence on Economic Preferences”, Quarterly Journal of Economics, 133 (4), 1645-1692 .

Falk, Armin, Anke Becker, Thomas Dohmen, David Huffman and Uwe Sunde, "The Preference Survey Module: A Validated Instrument for Measuring Risk, Time and Social Preferences”. 2016. IZA DP 9674

Figlio, David, Paola Giuliano, Umut Ozek and Paola Sapienza, 2019. "Long-Term Orientation and Educational Performance", American Economic Journal: Economic Policy, 11 (4): 272-309.

Galor, Oded and Omer Ozak, 2016, "The Agricultural Origins of Time Preference", American Economic Review, 106, 3064-3103 Hsin, Amy and Yu Xie, 2014, "Explaining Asian Americans' academic advantage over white", Proceedings of the National Academy of Science, 111 (23), 8416-8421.

Kahneman, Daniel and Alan B. Krueger, 2006. "Developments in the Measurement of Subjective Well-Being”, Journal of Economic Perspectives, 20 (1): 3-24.

Layard, Richard, 2011. Happiness: Lessons from a New Science, Penguin, UK.

Stevenson, Betsey and Justin Wolfers, 2008, "Economic Growth and Subjective Well- 
Being: Reassessing the Easterlin Paradox", Brookings Papers on Economic Activity, 39

(1), 1-102. 


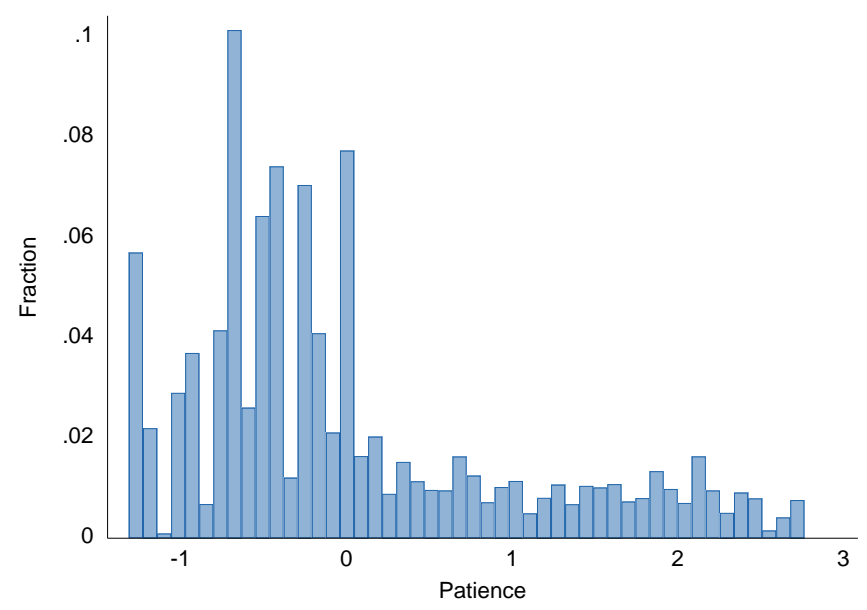

FIGURE 1.

PATIENCE, DENSITY FUNCTION

Note: The measure of patience is taken by Falk et al. (2018).

TABLE 1—LIFE SATISFACTION, EXPERIENCED WELL-BEING AND PATIENCE: INDIVIDUAL-LEVEL OLS ESTIMATES

\begin{tabular}{|c|c|c|c|c|c|c|c|c|c|}
\hline & Life Today & $\begin{array}{l}(2) \\
\text { Life in Five } \\
\text { Years }\end{array}$ & $\begin{array}{c}(3) \\
\text { Life } \\
\text { Evaluation } \\
\text { Index } \\
\end{array}$ & Happiness & $\begin{array}{c}\text { (5) } \\
\text { Smile or } \\
\text { Laugh }\end{array}$ & Enjoyment & $\begin{array}{c}(7) \\
\text { Worry }\end{array}$ & $\begin{array}{c}\text { (8) } \\
\text { Sadness }\end{array}$ & $\begin{array}{c}(9) \\
\text { Positive } \\
\text { Experience } \\
\text { Index } \\
\end{array}$ \\
\hline Patience & $\begin{array}{c}0.251 * * * \\
{[0.000]}\end{array}$ & $\begin{array}{c}0.273 * * * \\
{[0.000]}\end{array}$ & $\begin{array}{c}0.069 * * * \\
{[0.000]}\end{array}$ & $\begin{array}{c}0.018 * * * \\
{[0.000]}\end{array}$ & $\begin{array}{c}0.017 * * * \\
{[0.000]}\end{array}$ & $\begin{array}{c}0.022 * * * \\
{[0.000]}\end{array}$ & $\begin{array}{c}0.011 * * * \\
{[0.005]}\end{array}$ & $\begin{array}{c}0.014 * * * \\
{[0.000]}\end{array}$ & $\begin{array}{c}1.960 * * * \\
{[0.000]}\end{array}$ \\
\hline Patience Squared & $\begin{array}{c}-0.085^{* * *} \\
{[0.000]}\end{array}$ & $\begin{array}{c}-0.100 * * * \\
{[0.000]}\end{array}$ & $\begin{array}{c}-0.022 * * * \\
{[0.000]}\end{array}$ & $\begin{array}{c}-0.006 * * * \\
{[0.004]}\end{array}$ & $\begin{array}{c}-0.008 * * * \\
{[0.001]}\end{array}$ & $\begin{array}{c}-0.007 * * * \\
{[0.003]}\end{array}$ & $\begin{array}{c}-0.002 \\
{[0.361]}\end{array}$ & $\begin{array}{c}-0.005 * * * \\
{[0.003]}\end{array}$ & $\begin{array}{c}-0.698 * * * \\
{[0.000]}\end{array}$ \\
\hline $\begin{array}{l}\text { Measures of well-being } \\
\text { (mean and st. dev.) } \\
\text { Patience } \\
\text { (mean and st. dev.) } \\
\text { Optimal amount of } \\
\text { patience }\end{array}$ & $\begin{array}{c}5.625 \\
(2.284) \\
-0.022 \\
(0.992)\end{array}$ & $\begin{array}{c}6.655 \\
(2.417) \\
-0.001 \\
(0.996)\end{array}$ & $\begin{array}{l}1.156 \\
(0.621) \\
-0.001 \\
(0.996)\end{array}$ & $\begin{array}{c}0.712 \\
(0.453) \\
-0.031 \\
(0.987)\end{array}$ & $\begin{array}{c}0.722 \\
(0.448) \\
-0.033 \\
(0.986)\end{array}$ & $\begin{array}{c}0.707 \\
(0.455) \\
-0.032 \\
(0.986)\end{array}$ & $\begin{array}{c}0.630 \\
(0.483) \\
-0.033 \\
(0.985)\end{array}$ & $\begin{array}{c}0.761 \\
(0.426) \\
-0.033 \\
(0.986)\end{array}$ & $\begin{array}{c}68.610 \\
(28.560) \\
-0.034 \\
(0.985)\end{array}$ \\
\hline No. of Countries & 71 & 71 & 71 & 70 & 70 & 70 & 70 & 70 & 70 \\
\hline Observations & 73,164 & 67,740 & 67,634 & 70,996 & 71,449 & 71,784 & 72,300 & 72,228 & 72,802 \\
\hline R-squared & 0.265 & 0.244 & 0.23 & 0.111 & 0.094 & 0.087 & 0.079 & 0.079 & 0.135 \\
\hline
\end{tabular}

Notes: The unit of observation is an individual. The different measures of happiness are defined in the text. The measure of patience comes from Falk et al. (2018). All regressions include country fixed effects and the following individual controls: a quadratic in age, gender (a female dummy), education (dummies for having high school and up to some college, college or more - the excluded group is individuals with less than high school), marital status (dummies indicating if a person is married or in a domestic partnership, separated or divorced, single - the excluded group is widows), labor market status (dummies for unemployed and out of the labor force - the excluded group is employed individuals), and household income (expressed in log). Coefficients are reported with standard errors clustered at the country level. *** Significant at the 1 percent level. ** Significant at the 5 percent level. * Significant at the 10 percent level. 


\title{
Online Appendix for
}

\section{ThE COST OF BEING TOO PATIENT}

\author{
PAOLA GIULIANO \\ UCLA Anderson School of Management, NBER, CEPR and IZA \\ PAOLA SAPIENZA \\ Kellogg School of Management, NBER and CEPR \\ (NOT FOR PUBLICATION)
}

JANUARY 2020 


\section{A1. Introduction}

This appendix accompanies "The cost of being too-patient" by Paola Giuliano and Paola Sapienza. Section A2 reports additional tables that were referenced in the body of the paper, but not reported there.

\section{A2. Appendix Tables}

Table A1. Descriptive statistics

\begin{tabular}{|c|c|c|c|}
\hline VARIABLES & $\begin{array}{c}(1) \\
\text { Obs. } \\
\end{array}$ & $\begin{array}{c}(2) \\
\text { Mean } \\
\end{array}$ & $\begin{array}{l}(3) \\
\text { SD } \\
\end{array}$ \\
\hline \multicolumn{4}{|l|}{ Dependent Variables } \\
\hline Life Today $(0,10)$ & 73,164 & 5.62 & 2.28 \\
\hline Life in Five Years $(0,10)$ & 67,740 & 6.65 & 2.42 \\
\hline Life Evaluation Index $(1,3)$ & 67,634 & 2.16 & 0.62 \\
\hline Happiness (yes-no) & 70,996 & 0.71 & 0.45 \\
\hline Smile of Laugh (yes-no) & 71,449 & 0.72 & 0.45 \\
\hline Enjoyment (yes-no) & 71,784 & 0.71 & 0.46 \\
\hline Worry (yes-no), recoded & 72,300 & 0.63 & 0.48 \\
\hline Sadness (yes-no), recoded & 72,228 & 0.76 & 0.43 \\
\hline Positive Experience Index $(0,100)$ & 72,802 & 68.61 & 28.56 \\
\hline \multicolumn{4}{|l|}{ Independent Variables } \\
\hline Patience & 73,164 & -0.02 & 0.99 \\
\hline Age (divided by 10 ) & 73,164 & 4.15 & 1.73 \\
\hline Female & 73,164 & 0.55 & 0.5 \\
\hline Log(Household Income) & 73,164 & 9.15 & 1.49 \\
\hline Married/Domestic Partner & 73,164 & 0.59 & 0.49 \\
\hline Separated/Divorced & 73,164 & 0.06 & 0.24 \\
\hline Single/Never Married & 73,164 & 0.28 & 0.45 \\
\hline Unemployed & 73,164 & 0.06 & 0.25 \\
\hline Out of labor force & 73,164 & 0.39 & 0.49 \\
\hline High school and some college & 73,164 & 0.54 & 0.5 \\
\hline College and more & 73,164 & 0.16 & 0.37 \\
\hline
\end{tabular}


Table A2. Life satisfaction and patience: individual level OLS estimates

\begin{tabular}{|c|c|c|c|}
\hline & $\begin{array}{c}(1) \\
\text { Life Today }\end{array}$ & $\begin{array}{c}(2) \\
\text { Life in Five Years }\end{array}$ & $\begin{array}{c}(3) \\
\text { Life Evaluation Index }\end{array}$ \\
\hline Patience & $\begin{array}{c}0.251 * * * \\
{[0.000]}\end{array}$ & $\begin{array}{c}0.273 * * * \\
{[0.000]}\end{array}$ & $\begin{array}{c}0.069 * * * \\
{[0.000]}\end{array}$ \\
\hline Patience Squared & $\begin{array}{c}-0.085^{* * *} \\
{[0.000]}\end{array}$ & $\begin{array}{c}-0.100 * * * \\
{[0.000]}\end{array}$ & $\begin{array}{c}-0.022 * * * \\
{[0.000]}\end{array}$ \\
\hline Age & $\begin{array}{c}-0.444^{* * *} \\
{[0.000]}\end{array}$ & $\begin{array}{c}-0.426^{* * *} \\
{[0.000]}\end{array}$ & $\begin{array}{c}-0.098^{* * *} \\
{[0.000]}\end{array}$ \\
\hline Age Squared & $\begin{array}{c}0.039 * * * \\
{[0.000]}\end{array}$ & $\begin{array}{c}0.016^{* *} \\
{[0.037]}\end{array}$ & $\begin{array}{c}0.005^{* * *} \\
{[0.004]}\end{array}$ \\
\hline Female & $\begin{array}{c}0.154 * * * \\
{[0.000]}\end{array}$ & $\begin{array}{c}0.187 * * * \\
{[0.000]}\end{array}$ & $\begin{array}{c}0.043^{* * *} \\
{[0.000]}\end{array}$ \\
\hline Log(Income) & $\begin{array}{c}0.253^{* * *} \\
{[0.000]}\end{array}$ & $\begin{array}{c}0.238^{* * *} \\
{[0.000]}\end{array}$ & $\begin{array}{c}0.061 * * * \\
{[0.000]}\end{array}$ \\
\hline Married & $\begin{array}{c}0.288^{* * *} \\
{[0.000]}\end{array}$ & $\begin{array}{c}0.168^{* * *} \\
{[0.006]}\end{array}$ & $\begin{array}{c}0.054^{* * *} \\
{[0.000]}\end{array}$ \\
\hline Separated/Divorced & $\begin{array}{l}-0.011 \\
{[0.848]}\end{array}$ & $\begin{array}{c}0.015 \\
{[0.807]}\end{array}$ & $\begin{array}{l}-0.017 \\
{[0.270]}\end{array}$ \\
\hline Single & $\begin{array}{c}0.258^{* * *} \\
{[0.000]}\end{array}$ & $\begin{array}{c}0.206^{* * *} \\
{[0.001]}\end{array}$ & $\begin{array}{c}0.049 * * * \\
{[0.001]}\end{array}$ \\
\hline Unemployed & $\begin{array}{c}-0.450 * * * \\
{[0.000]}\end{array}$ & $\begin{array}{c}-0.323^{* * *} \\
{[0.000]}\end{array}$ & $\begin{array}{c}-0.099 * * * \\
{[0.000]}\end{array}$ \\
\hline Out of labor force & $\begin{array}{l}-0.010 \\
{[0.744]}\end{array}$ & $\begin{array}{c}-0.105^{* * *} \\
{[0.001]}\end{array}$ & $\begin{array}{c}-0.018^{* *} \\
{[0.044]}\end{array}$ \\
\hline Secondary and some college & $\begin{array}{c}0.414^{* * *} \\
{[0.000]}\end{array}$ & $\begin{array}{c}0.390 * * * \\
{[0.000]}\end{array}$ & $\begin{array}{c}0.086^{* * *} \\
{[0.000]}\end{array}$ \\
\hline College and more & $\begin{array}{c}0.799 * * * \\
{[0.000]}\end{array}$ & $\begin{array}{c}0.766^{* * *} \\
{[0.000]}\end{array}$ & $\begin{array}{c}0.200^{* * *} \\
{[0.000]}\end{array}$ \\
\hline Observations & 73,164 & 67,740 & 67,634 \\
\hline R-squared & 0.265 & 0.244 & 0.230 \\
\hline Measures of well-being mean & 5.625 & 6.655 & 2.156 \\
\hline Measures of well-being st. dev. & 2.284 & 2.417 & 0.621 \\
\hline Patience mean & -0.0217 & -0.00136 & -0.00114 \\
\hline Patience st. dev. & 0.992 & 0.996 & 0.996 \\
\hline Optimal amount of patience & 1.483 & 1.361 & 1.564 \\
\hline No. of Countries & 71 & 71 & 71 \\
\hline
\end{tabular}

Notes: The unit of observation is an individual. The different measures of happiness are defined in the text. The measure of patience comes from Falk et al. (2018). All regressions include country fixed effects and the following individual controls: a quadratic in age, gender (a female dummy), education (dummies for having high school and up to some college, college or more - the excluded group is individuals with less than high school), marital status (dummies indicating if a person is married or in a domestic partnership, separated or divorced, single - the excluded group is widows), labor market status (dummies for unemployed and out of the labor force - the excluded group is employed individuals), and household income (expressed in log). Coefficients are reported with standard errors clustered at the country level. *** Significant at the 1 percent level. $* *$ Significant at the 5 percent level. * Significant at the 10 percent level. 
Table A3. Life satisfaction and patience: individual level OLS estimates, with limited set of controls

\begin{tabular}{|c|c|c|c|}
\hline & $\begin{array}{c}(1) \\
\text { Life Today }\end{array}$ & $\begin{array}{c}(2) \\
\text { Life in Five Years }\end{array}$ & $\begin{array}{c}\text { (3) } \\
\text { Life Evaluation Index }\end{array}$ \\
\hline Patience & $\begin{array}{c}0.312^{* * *} \\
{[0.000]}\end{array}$ & $\begin{array}{c}0.327 * * * \\
{[0.000]}\end{array}$ & $\begin{array}{c}0.084 * * * \\
{[0.000]}\end{array}$ \\
\hline Patience Squared & $\begin{array}{c}-0.101 * * * \\
{[0.000]}\end{array}$ & $\begin{array}{c}-0.114 * * * \\
{[0.000]}\end{array}$ & $\begin{array}{c}-0.026 * * * \\
{[0.000]}\end{array}$ \\
\hline Age & $\begin{array}{c}-0.357^{* * *} \\
{[0.000]}\end{array}$ & $\begin{array}{c}-0.325^{* * *} \\
{[0.000]}\end{array}$ & $\begin{array}{c}-0.069 * * * \\
{[0.000]}\end{array}$ \\
\hline Age Squared & $\begin{array}{c}0.024 * * * \\
{[0.000]}\end{array}$ & $\begin{array}{l}-0.001 \\
{[0.840]}\end{array}$ & $\begin{array}{c}0.001 \\
{[0.683]}\end{array}$ \\
\hline Female & $\begin{array}{c}0.079 * * * \\
{[0.003]}\end{array}$ & $\begin{array}{c}0.105^{* * *} \\
{[0.001]}\end{array}$ & $\begin{array}{c}0.024 * * * \\
{[0.001]}\end{array}$ \\
\hline Observations & 76,802 & 71,205 & 71,088 \\
\hline R-squared & 0.229 & 0.217 & 0.203 \\
\hline Measures of well-being mean & 5.663 & 6.704 & 2.167 \\
\hline Measures of well-being st. dev. & 2.286 & 2.410 & 0.621 \\
\hline Patience mean & 0.00153 & 0.0221 & 0.0224 \\
\hline Patience st. dev. & 1.002 & 1.006 & 1.006 \\
\hline Optimal amount of patience & 1.553 & 1.430 & 1.627 \\
\hline No. of Countries & 74 & 74 & 74 \\
\hline
\end{tabular}

Notes: The unit of observation is an individual. The different measures of happiness are defined in the text. The measure of patience comes from Falk et al. (2018). All regressions include country fixed effects, a quadratic in age and gender (a female dummy). Coefficients are reported with standard errors clustered at the country level. *** Significant at the 1 percent level. ** Significant at the 5 percent level. * Significant at the 10 percent level. 
Table A3. Experienced well-being and patience: individual level OLS estimates, with limited set of controls (continued)

\begin{tabular}{|c|c|c|c|c|c|c|}
\hline & $\begin{array}{c}(4) \\
\text { Happiness }\end{array}$ & $\begin{array}{c}\text { (5) } \\
\text { Smile of Laugh }\end{array}$ & $\begin{array}{c}\text { (6) } \\
\text { Enjoyment }\end{array}$ & $\begin{array}{c}(7) \\
\text { Worry }\end{array}$ & $\begin{array}{c}(8) \\
\text { Sadness }\end{array}$ & $\begin{array}{c}(9) \\
\text { Positive Experience Index }\end{array}$ \\
\hline Patience & $\begin{array}{c}0.023 * * * \\
{[0.000]}\end{array}$ & $\begin{array}{c}0.021 * * * \\
{[0.000]}\end{array}$ & $\begin{array}{c}0.027 * * * \\
{[0.000]}\end{array}$ & $\begin{array}{c}0.014 * * * \\
{[0.000]}\end{array}$ & $\begin{array}{c}0.019 * * * \\
{[0.000]}\end{array}$ & $\begin{array}{c}2.373 * * * \\
{[0.000]}\end{array}$ \\
\hline Patience Squared & $\begin{array}{c}-0.008 * * * \\
{[0.000]}\end{array}$ & $\begin{array}{c}-0.009 * * * \\
{[0.000]}\end{array}$ & $\begin{array}{c}-0.008 * * * \\
{[0.000]}\end{array}$ & $\begin{array}{l}-0.003 \\
{[0.193]}\end{array}$ & $\begin{array}{c}-0.007 * * * \\
{[0.000]}\end{array}$ & $\begin{array}{c}-0.804 * * * \\
{[0.000]}\end{array}$ \\
\hline Age & $\begin{array}{c}-0.058^{* * *} \\
{[0.000]}\end{array}$ & $\begin{array}{c}-0.055^{* * *} \\
{[0.000]}\end{array}$ & $\begin{array}{c}-0.058^{* * * *} \\
{[0.000]}\end{array}$ & $\begin{array}{c}-0.093^{* * * *} \\
{[0.000]}\end{array}$ & $\begin{array}{c}-0.027^{* * *} \\
{[0.000]}\end{array}$ & $\begin{array}{c}-5.297^{* * *} \\
{[0.000]}\end{array}$ \\
\hline Age Squared & $\begin{array}{c}0.003^{* * *} \\
{[0.000]}\end{array}$ & $\begin{array}{c}0.002^{* * *} \\
{[0.002]}\end{array}$ & $\begin{array}{c}0.003^{* * *} * \\
{[0.001]}\end{array}$ & $\begin{array}{c}0.008^{* * *} \\
{[0.000]}\end{array}$ & $\begin{array}{c}0.000 \\
{[0.602]}\end{array}$ & $\begin{array}{c}0.346^{* * *} \\
{[0.000]}\end{array}$ \\
\hline Female & $\begin{array}{c}0.001 \\
{[0.883]}\end{array}$ & $\begin{array}{c}0.014^{* * *} \\
{[0.004]}\end{array}$ & $\begin{array}{l}-0.006 \\
{[0.223]}\end{array}$ & $\begin{array}{c}-0.041 * * * \\
{[0.000]}\end{array}$ & $\begin{array}{c}-0.054^{* * *} \\
{[0.000]}\end{array}$ & $\begin{array}{c}-0.614^{* *} \\
{[0.045]}\end{array}$ \\
\hline Observations & 73,538 & 74,011 & 74,362 & 74,903 & 74,822 & 75,415 \\
\hline R-squared & 0.097 & 0.085 & 0.075 & 0.070 & 0.064 & 0.115 \\
\hline Measures of well-being mean & 0.714 & 0.724 & 0.708 & 0.633 & 0.763 & 68.77 \\
\hline Measures of well-being st. dev. & 0.452 & 0.447 & 0.455 & 0.482 & 0.425 & 28.53 \\
\hline Patience mean & -0.0196 & -0.0210 & -0.0207 & -0.0218 & -0.0215 & -0.0222 \\
\hline Patience st. dev. & 0.990 & 0.990 & 0.990 & 0.989 & 0.989 & 0.989 \\
\hline Optimal amount of patience & 1.508 & 1.116 & 1.609 & 2.679 & 1.450 & 1.476 \\
\hline No. of Countries & 72 & 72 & 72 & 72 & 72 & 72 \\
\hline
\end{tabular}


Table A4. Life evaluation index and patience: individual level OLS estimates, by sub-groups

\begin{tabular}{|c|c|c|c|c|c|c|c|c|c|c|c|c|c|c|}
\hline & \multicolumn{14}{|c|}{ Dependent Variable: Life Evaluation Index } \\
\hline & \multirow{2}{*}{\multicolumn{2}{|c|}{$\begin{array}{c}\text { (1) } \\
\text { Country-Level Patience } \\
\end{array}$}} & \multirow{2}{*}{\multicolumn{2}{|c|}{ Age }} & \multirow{3}{*}{\multicolumn{2}{|c|}{\begin{tabular}{ll}
\multicolumn{2}{c}{ Gender } \\
Male & Female
\end{tabular}}} & \multirow{2}{*}{\multicolumn{2}{|c|}{$\begin{array}{l}(7) \quad(8) \\
\text { Household Income }\end{array}$}} & \multirow{2}{*}{\multicolumn{2}{|c|}{$\begin{array}{l}(9) \\
\text { Marriage Status }\end{array}$}} & \multirow{2}{*}{\multicolumn{2}{|c|}{ Employment }} & \multirow{2}{*}{\multicolumn{2}{|c|}{${ }_{\text {Education }}^{(14)}$}} \\
\hline & & & & & & & & & & & & & & \\
\hline & Below Median & Above Median & Below Median & Above Median & & & Below Median & Above Median & Married & Other & Employed & Other & No College & College+ \\
\hline Patience & $\begin{array}{l}0.066 * * * \\
{[0.000]}\end{array}$ & $\begin{array}{c}0.073^{* * *} \\
{[0.000]}\end{array}$ & $\begin{array}{l}0.064 * * * \\
{[0.000]}\end{array}$ & $\begin{array}{l}0.070^{* * *} \\
{[0.000]}\end{array}$ & $\begin{array}{l}0.081 * * * \\
{[0.000]}\end{array}$ & $\begin{array}{l}0.058^{* * *} \\
{[0.000]}\end{array}$ & $\begin{array}{l}0.071 * * * \\
{[0.0001}\end{array}$ & $0.061 * * *$ & $0.067 * * *$ & $\begin{array}{l}0.071 * * * \\
{[0.0001}\end{array}$ & $\begin{array}{l}0.063 * * * \\
{[0.0001}\end{array}$ & $\begin{array}{l}0.074 * * * \\
\ulcorner 0.0001\end{array}$ & $\begin{array}{l}0.073 * * * \\
\ulcorner 0.0001\end{array}$ & $\begin{array}{l}0.056 * * * \\
\ulcorner 0.0001\end{array}$ \\
\hline Patience Squared & $\begin{array}{c}-0.021 * * * \\
{[0.000]}\end{array}$ & $\begin{array}{c}-0.024 * * * \\
{[0.000]}\end{array}$ & $\begin{array}{c}-0.020 * * * \\
{[0.000]}\end{array}$ & $\begin{array}{c}-0.022^{* * *} \\
{[0.000]}\end{array}$ & $\begin{array}{c}-0.025 * * * \\
{[0.000]}\end{array}$ & $\begin{array}{c}-0.020 * * * \\
{[0.000]}\end{array}$ & $\begin{array}{c}-0.028 * * * \\
{[0.000]}\end{array}$ & $\begin{array}{c}-0.014 * * * \\
{[0.001]}\end{array}$ & $\begin{array}{c}-0.022 * * * \\
{[0.000]}\end{array}$ & $\begin{array}{c}-0.022 * * * \\
{[0.000]}\end{array}$ & $\begin{array}{c}-0.019 * * * \\
{[0.000]}\end{array}$ & $\begin{array}{c}-0.025 * * * \\
{[0.000]}\end{array}$ & $\begin{array}{c}-0.024 * * * \\
{[0.000]}\end{array}$ & $\begin{array}{c}-0.017 * * * \\
{[0.003]}\end{array}$ \\
\hline Observations & 35,520 & 32,114 & 36,687 & 31,111 & 30,935 & 36,699 & 34,310 & 34,299 & 39,474 & 28,448 & 37,163 & 32,388 & 56,914 & 10,929 \\
\hline R-squared & 0.207 & 0.226 & 0.223 & 0.240 & 0.229 & 0.236 & 0.164 & 0.193 & 0.234 & 0.231 & 0.247 & 0.222 & 0.209 & 0.226 \\
\hline Measures of well-being mean & 2.075 & 2.245 & 2.201 & 2.103 & 2.141 & 2.169 & 1.997 & 2.315 & 2.146 & 2.171 & 2.201 & 2.128 & 2.114 & 2.374 \\
\hline Measures of well-being st. dev. & 0.619 & 0.611 & 0.600 & 0.642 & 0.620 & 0.623 & 0.595 & 0.602 & 0.623 & 0.618 & 0.614 & 0.630 & 0.616 & 0.603 \\
\hline Patience mean & -0.267 & 0.293 & -0.00628 & 0.00678 & 0.0387 & -0.0347 & -0.184 & 0.185 & 0.00858 & -0.0145 & 0.0813 & -0.0475 & -0.0605 & 0.308 \\
\hline Patience st. dev. & 0.827 & 1.080 & 0.962 & 1.035 & 1.013 & 0.980 & 0.899 & 1.051 & 1.006 & 0.981 & 1.023 & 0.985 & 0.962 & 1.106 \\
\hline Optimal amount of patience & 1.547 & 1.533 & 1.597 & 1.591 & 1.647 & 1.456 & 1.264 & 2.233 & 1.551 & 1.576 & 1.635 & 1.499 & 1.522 & 1.642 \\
\hline No. of Countries & 37 & 34 & 71 & 71 & 71 & 71 & 71 & 72 & 71 & 71 & 71 & 73 & 71 & 71 \\
\hline
\end{tabular}


Table A5. Positive experience index and patience: individual level OLS estimates, by sub-groups

\begin{tabular}{|c|c|c|c|c|c|c|c|c|c|c|c|c|c|c|}
\hline & \multicolumn{14}{|c|}{ Dependent Variable: Positive Experience Index } \\
\hline & (1) & (2) & \multirow[t]{2}{*}{ (3) } & \multirow[t]{2}{*}{ (4) } & \multirow[t]{2}{*}{ (5) } & \multirow{2}{*}{ er } & \multirow{2}{*}{\multicolumn{2}{|c|}{$\begin{array}{l}(7) \quad(8) \\
\text { Household Income }\end{array}$}} & \multirow{2}{*}{\multicolumn{2}{|c|}{$\begin{array}{c}(9) \quad(10) \\
\text { Marriage Status } \\
\end{array}$}} & (11) & (12) & \multirow{2}{*}{\multicolumn{2}{|c|}{ (13) ${ }_{\text {Education }}^{(14)}$}} \\
\hline & \multicolumn{2}{|c|}{ Country-Level Patience } & & & & & & & & & \multicolumn{2}{|c|}{$\begin{array}{l}\text { (11) } \\
\text { Employment }\end{array}$} & & \\
\hline & Below Median & Above Median & Below Median & Above Median & Male & Female & Below Median & Above Median & Married & Other & Employed & Other & No College & Colleget \\
\hline Patience & $\begin{array}{c}1.775 * * * \\
{[0.000]}\end{array}$ & $\begin{array}{c}2.214 * * * \\
{[0.000]}\end{array}$ & $\begin{array}{c}1.634 * * * \\
{[0.000]}\end{array}$ & $\begin{array}{c}2.134 * * * \\
{[0.000]}\end{array}$ & $\begin{array}{c}2.143 * * * \\
{[0.000]}\end{array}$ & $\begin{array}{c}1.760 * * * \\
{[0.000]}\end{array}$ & $\begin{array}{c}1.920 * * * \\
{[0.000]}\end{array}$ & $\begin{array}{c}1.786 * * * \\
{[0.000]}\end{array}$ & $\begin{array}{c}1.807 * * * \\
{[0.000]}\end{array}$ & $\begin{array}{c}2.154 * * * \\
{[0.000]}\end{array}$ & $\begin{array}{c}1.685 * * * \\
{[0.000]}\end{array}$ & $\begin{array}{c}2.066 * * * \\
{[0.000]}\end{array}$ & $\begin{array}{c}2.167 * * * \\
{[0.000]}\end{array}$ & $\begin{array}{l}1.052 * * \\
{[0.028]}\end{array}$ \\
\hline Patience Squared & $\begin{array}{c}-0.544 * * \\
{[0.012]}\end{array}$ & $\begin{array}{c}-0.837 * * * \\
{[0.000]}\end{array}$ & $\begin{array}{c}-0.576 * * * \\
{[0.002]}\end{array}$ & $\begin{array}{c}-0.719 * * * \\
{[0.000]}\end{array}$ & $\begin{array}{c}-0.746 * * * \\
{[0.000]}\end{array}$ & $\begin{array}{c}-0.652 * * * \\
{[0.000]}\end{array}$ & $\begin{array}{c}-0.711 * * * \\
{[0.000]}\end{array}$ & $\begin{array}{c}-0.540 * * * \\
{[0.002]}\end{array}$ & $\begin{array}{c}-0.618 * * * \\
{[0.000]}\end{array}$ & $\begin{array}{c}-0.816 * * * \\
{[0.000]}\end{array}$ & $\begin{array}{c}-0.604 * * * \\
{[0.000]}\end{array}$ & $\begin{array}{c}-0.682 * * * \\
{[0.000]}\end{array}$ & $\begin{array}{c}-0.793 * * * \\
{[0.000]}\end{array}$ & $\begin{array}{l}-0.270 \\
{[0.304]}\end{array}$ \\
\hline Observations & 39,421 & 33,381 & 38,801 & 34,166 & 32,950 & 39,852 & 37,717 & 36,082 & 42,677 & 30,448 & 39,152 & 34,626 & 61,821 & 11,239 \\
\hline R-squared & 0.147 & 0.117 & 0.105 & 0.162 & 0.136 & 0.137 & 0.148 & 0.106 & 0.124 & 0.154 & 0.116 & 0.160 & 0.137 & 0.105 \\
\hline Measures of well-being mean & 67.60 & 69.81 & 71.15 & 65.73 & 68.86 & 68.41 & 66.02 & 71.54 & 68.01 & 69.38 & 69.60 & 67.67 & 67.91 & 72.43 \\
\hline Measures of well-being st. dev. & 29.12 & 27.84 & 27.70 & 29.22 & 28.47 & 28.63 & 29.51 & 27.21 & 28.29 & 28.95 & 28.12 & 28.96 & 28.74 & 27.22 \\
\hline Patience mean & -0.281 & 0.258 & -0.0236 & -0.0438 & 0.00410 & -0.0649 & -0.202 & 0.146 & -0.0254 & -0.0448 & 0.0533 & -0.111 & -0.0858 & 0.252 \\
\hline Patience st. dev. & 0.825 & 1.074 & 0.955 & 1.019 & 1.002 & 0.970 & 0.893 & 1.042 & 0.994 & 0.972 & 1.013 & 0.955 & 0.954 & 1.096 \\
\hline Optimal amount of patience & 1.633 & 1.323 & 1.417 & 1.484 & 1.436 & 1.349 & 1.350 & 1.652 & 1.463 & 1.320 & 1.394 & 1.514 & 1.366 & 1.948 \\
\hline No. of Countries & 37 & 33 & 70 & 70 & 70 & 70 & 70 & 71 & 70 & 70 & 70 & 71 & 70 & 70 \\
\hline
\end{tabular}

